\title{
Dokumentacija Etnografskoga muzeja u Zagrebu
}

- Rad donosi sažeti prikaz dokumentarističke djelatnosti u Etnografskom muzeju u Zagrebu od 1919. godine do danas. Nastoji uputiti na značaj, ali i promjenu te proširenje uloge dokumentacije u muzejima tijekom vremena. Istaknut je kontinuitet vođenja dokumentacije u Etnografskom muzeju tijekom 100 godina njegova djelovanja te ukratko predstavljen rad osoba koje su imale ključnu ulogu u formiranju i vođenju dokumentacije Muzeja. U zaključnom dijelu predstavljeni su trenutni izazovi i nastojanja da se tradicija vođenja dokumentacije uskladi s promjenama zakona, razvojem tehnologije i međunarodnim standardima.

\section{Ključne riječi: Etnografski muzej (Zagreb)}

muzejska dokumentacija, fundus muzeja, inventarizacija građe

\section{UVOD}

Vođenje dokumentacije o muzejskim predmetima u Etnografskom muzeju započelo je odmah po osnutku muzeja 1919. godine te su ubrzo formirani i dokumentacijski fondovi, čime su stvoreni kvalitetni temelji muzejske dokumentacije koji su nadograđivani do danas.

Praksu i načine vođenja muzejske dokumentacije nastojala sam za potrebe ovoga teksta rekonstruirati uvidom i analizom u trenutno dostupnu dokumentacijsku i arhivsku građu Etnografskoga muzeja te literaturu koja se odnosi na povijest, organizaciju i djelovanje Muzeja. Uz navedeno koristila sam trenutno važeće zakone i pravilnike koji se odnose 
na muzejsku djelatnost te literaturu koja se bavi pozicijom i definiranjem muzejske dokumentacije kroz zakone i pravilnike iz ranijih razdoblja. ${ }^{1}$

Cilj rada je prikazati povijesni pregled i kontinuitet vođenja dokumentacije u Etnografskom muzeju, predstaviti trenutne aktivnosti i planove vezane uz dokumentaciju te ukazati na ulogu i važnost muzejske dokumentacije ne samo u Etnografskom, već i u muzejima općenito.

Na početku teksta kratko sam se osvrnula na pojam muzejske dokumentacije kroz zakonsku regulativu kako bih dodatno naglasila razvijenu svijest o važnosti vođenja dokumentacije o muzejskoj i dokumentacijskoj građi od osnutka Etnografskoga muzeja. U poglavlju koje slijedi prikazana je povijest vođenja dokumentacije te je predstavljen rad osoba koje su imale ključnu ulogu u formiranju i vođenju dokumentacije Muzeja. Zaključno poglavlje donosi opis trenutne situacije u Dokumentaciji Etnografskoga muzeja, od načina i plana (re)sistematizacije fondova sekundarne dokumentacije, sistematizacije i obrade dokumentacijske građe, sređivanja primarne dokumentacije do rada na tercijarnoj dokumentaciji.

\section{MUZEJSKA DOKUMENTACIJA KROZ NORMATIVNE AKTE}

Muzejska dokumentacija i dokumentacijska građa u praksi su dugo imale podređen položaj u usporedbi s muzejskom građom te je relativno kasno obuhvaćena i definirana kroz normativne akte. Nastojanje da se muzejska djelatnost regulira zakonom u nekadašnjoj Jugoslaviji počinje još tijekom 1. polovice 20. stoljeća te se intenzivira sredinom stoljeća kada su i doneseni prvi zakoni o muzejima u republikama bivše države. U Hrvatskoj je prvi “Zakon o muzejskoj djelatnosti” donesen 1960. godine (NN 49/1960) te je izmijenjen i dopunjen 1965. godine (Oklopčić 1990: 26). U isto to vrijeme, 1962. godine, Savjet za kulturu NR Hrvatske propisao je "Uputstva o načinu vođenja knjiga muzejske građe i kartoteka u muzejima i muzejskim zbirkama" (Šola ur. 1987: 7). U "Zakonu o muzejskoj djelatnosti" koji je donesen 1977. godine (NN 12/1977) oblik i način vođenja muzejske dokumentacije ne definira se, već se u članku 11 navodi: "Muzejske organizacije dužne su voditi inventar, knjige evidencije i kartoteke predmeta muzejske građe na način kako to propiše Muzejski savjet Hrvatske" (Šola ur. 1987: 7; Osrečki 1990: 27). Godine 1989. Muzejski savjet Hrvatske donio je "Upute o osnovama za vođenje dokumentacije o predmetima muzejske građe" kojima se nastojalo definirati te kod stručnjaka osvijestiti i potaknuti proces stvaranja normirane i jedinstvene muzejske dokumentacije. ${ }^{2}$

1 Dokumentacija Etnografskoga muzeja bila mi je tema pismenoga dijela stručnoga ispita za zvanje dokumentarist 2018. godine koji je u ovom tekstu preformuliran i nadopunjen novim spoznajama. S obzirom da u Etnografskom muzeju radim od kraja 2016. godine te da je tek ove godine započet proces (re)sistematizacije dokumentacijskih fondova i građe podatci i rezultati navedeni u ovom tekstu temelje se na dosadašnjem uvidu u dokumentacijsku i arhivsku građu muzeja koja je zbog radova tek djelomice dostupna. Vjerujem da će sistematizacija i obrada dokumentacijske građe koje slijede zasigurno donijeti nove spoznaje.

2 CIDOC-ova (Komitet za dokumentaciju ICOM-a, Međunarodnoga komiteta za muzeje) lista minimuma podataka predložena je 1980. godine te se trebala primjenjivati na svim nacionalnim razinama. Već 1981. godine na sastanku CIDOC-a zaključeno je da predloženu listu treba proširiti kategorijama podataka za pojedinačne discipline (Šola ur. 1987: 8). 
Zakon o muzejima (NN 142/1998) donesen 1998. godine načelnim odredbama obuhvaća pojam muzejske dokumentacije te navodi da su sve muzejske institucije dužne voditi dokumentaciju o muzejskoj građi (Zakon 1998, čl. 7). Pri tome muzejska dokumentacija podrazumijeva "podatke o muzejskim predmetima koji su potrebni za njihovu stručnu obradu, identifikaciju, određivanje podrijetla i stanja u kojem su pribavljeni, te za uvid u stanje muzejske građe", a "sadržaj i način vođenja muzejske dokumentacije o muzejskoj građi pravilnikom propisuje ministar kulture na prijedlog Hrvatskoga muzejskog vijeća" (Zakon 1998, čl. 8). Odredbom članka 7 toga Zakona muzejska dokumentacija izjednačena je s muzejskom građom kada je riječ o zaštiti i očuvanju.

Uslijedilo je donošenje "Pravilnika o sadržaju i načinu vođenja muzejske dokumentacije o muzejskoj građi” (NN 108/2002) koji je u stvari prvi propis kojim se pobliže definira sadržaj, oblike i načine vođenja muzejske dokumentacije. Taj Pravilnik dokumentaciju dijeli na primarnu, sekundarnu i tercijarnu. ${ }^{3}$ Definira je kao "sustavno izrađen, prikupljen, organiziran i pohranjen skup podataka, koji je nastao u tijeku procesa stručne obrade, zaštite i prezentacije muzejske građe, te se temelji na dogovorenom i utvrđenom broju i kvaliteti podataka o predmetu, grupi predmeta ili cjelokupnom fondu. Muzejska dokumentacija se stvara u postupcima inventarizacije, katalogiziranja i indeksiranja, koji predstavljaju trajan proces obrade i nadopunjavanja podataka" (Pravilnik 2002, čl. 2).

"Svrha je vođenja muzejske dokumentacije da se preko pregledno i sustavno obrađenih fondova pruži točna informacija o muzejskoj građi, njezinu stanju, izložbama, drugim manifestacijama i aktivnostima muzeja, te o povijesti muzeja sa stručnog i znanstvenog aspekta" (Pravilnik 2002, čl. 3).

Uz navedeno treba spomenuti i "Pravilnik o stručnim i tehničkim standardima za određivanje vrste muzeja, za njihov rad, te za smještaj muzejske građe i muzejske dokumentacije" (NN 30/2006), donesen 2006. godine, kojim su pobliže utvrđene odredbe vezane uz zaštitu muzejske dokumentacije.

3 Podjela muzejske dokumentacije na primarnu, sekundarnu i tercijarnu bila je prisutna i prije spomenutoga Pravilnika. Muzeolog Ivo Maroević dokumentaciju dijeli i objašnjava prema sadržaju i funkciji. Primarna dokumentacija nastaje u neposrednom dodiru s predmetima, a podatci o njima nastaju "istraživanjem, zaštitom i komuniciranjem predmeta baštine, pokrivaju njihovo poznavanje i sve vrste zbivanja u njima i oko njih ili zbivanja u kojima je predmet subjekt ili objekt" (Maroević 1993: 191). Stoga Maroević kao dio primarne dokumentacije shvaća i građu dokumentacijskih zbirki poput planoteke, fototeke, hemeroteke, zbirke uzoraka, fonoteke, filmoteke, videoteke ili dijateke. Sekundarna dokumentacija obuhvaća prijenos primarne dokumentacije u druge medije (mikrofilm, magnetne vrpce, diskete). Tercijarnu čine "pregledi, kartoteke, katalozi, indeksi, popisi i svi drugi oblici pregleda nad dokumentacijom" (Maroević 1993: 192-193). Uvođenjem suvremene tehnologije i razvojem muzeologije redefiniraju se vrste dokumentacije. Prema Pravilniku o sadržaju i načinu vođenja muzejske dokumentacije o muzejskoj građi (NN 108/2002) primarna dokumentacija "obuhvaća prvu i najveću skupinu podataka o muzejskoj građi. Dobiveni podatci rezultat su evidentiranja, analize i stručne obrade predmeta. Primarnu dokumentaciju čine: inventarna knjiga muzejskih predmeta, katalog muzejskih predmeta, knjiga ulaska muzejskih predmeta, knjiga izlaska muzejskih predmeta, knjiga pohrane muzejskih predmeta i zapisnici o reviziji muzejske građe" (Pravilnik 2002, čl. 5). Sekundarna dokumentacija "obuhvaća popratne i dopunske fondove muzejske djelatnosti. Sekundarni muzejski fondovi mogu biti organizirani prema medijima prikazivanja i prema sadržaju. Sekundarnu muzejsku dokumentaciju čine: inventarne knjige audio-vizualnih fondova, inventarna knjiga hemeroteke, knjiga evidencije o izložbama, evidencija o konzervatorsko-restauratorskim postupcima, evidencija o pedagoškoj djelatnosti, evidencija o stručnom i znanstvenom radu, evidencija o izdavačkoj djelatnosti, dokumentacija o marketingu i odnosima s javnošću te dokumentacija o osnivanju i povijesti muzeja“ (Pravilnik 2002, čl. 23). Tercijarnu dokumentaciju "čine pomagala u obliku raznovrsnih kataloga i indeksa: predmetnih, autorskih, kronoloških, topografskih i drugih, primjerenih djelatnosti muzeja“. Generira se "iz fondova primarne i sekundarne dokumentacije u obliku tezaurusa, indeksa, kataloških listića i sažetaka, a u funkciji je bržeg pretraživanja i korištenja podataka iz postojećih dokumentacijskih fondova“" (Pravilnik 2002, čl. 38). 


\section{DOKUMENTACIJA U USTROJSTVU ETNOGRAFSKOGA MUZEJA U ZAGREBU}

Godine 1961. donesen je dokument "Pravila Etnografskog muzeja" u kojem se među ostalim definira i unutrašnja organizacija muzeja. ${ }^{4}$ Muzej je tada organiziran kroz četiri odjela: Opći odjel, Stručno-naučni odjel, Stručni odjel i Stručno-tehnički odjel. Ono što se danas smatra dokumentacijom Etnografskoga muzeja prema podjeli iz navedenoga dokumenta svrstano je u Odjel ilustrativnoga naučnog materijala i rukopisa (dio Stručno-naučnoga odjela), ${ }^{5}$ Odjel dokumentacije (dio Stručnoga odjela) ${ }^{6}$ te Odjel inventara i depoa - muzejski inventar i katalog (dio Stručno tehničkoga odjela). ${ }^{7}$

Prema unutrašnjoj organizaciji iz Statuta Etnografskoga muzeja u Zagrebu od 14. studenoga 1966. godine te Pravilnika o sistematizaciji radnih mjesta iz iste godine poslovi vođenja dokumentacije uvršteni su u odsjek Inventara unutar Odjela inventara i depoa (dio Odjela stručno-naučnoga rada) te odsjek Dokumentacija unutar Odjela biblioteka i dokumentacija (dio Odjela stručno-naučnoga rada). ${ }^{8}$ U Pravilniku su navedena sljedeća radna mjesta koja se odnose na poslove vezane uz vođenje dokumentacije: stručnjak za vođenje dokumentacije te stručnjak za vođenje inventara etnografske građe. ${ }^{9}$

4 Pohranjen u Dokumentaciji Etnografskoga muzeja. Detaljnijim uvidom u arhivsku građu tijekom budućih istraživanja potrebno je utvrditi je li to prvi dokument koji definira organizaciju Muzeja ili je definirana i u prijašnjim razdobljima.

5 U Odjel ilustrativnoga, naučnoga materijala i rukopisa ulazila je sljedeća građa: "crteži, grafika, ulja, i ostali materijal, koji služi u stručno naučnom radu, te dragocjena rukopisna građa, kao i sva ona rukopisna građa s terena, koja redovno pridolazi u muzej; inventiranje, katalogiziranje, te naučna obrada gore imenovane građe." (Pravila Etnografskoga muzeja 1961.).

6 Odjel dokumentacije obuhvaća "pronalaženje, prikupljanje, sređivanje, čuvanje, inventiranje, signiranje, ostručivanje i katalogiziranje svih vrsti dokumentacije za historiju muzeja i djelatnosti u vezi s muzejom i izvan njega, kako prošlih tako i aktualnih, u suradnji s arhivskom službom Općeg odjela. Služba dokumentacije u suradnji s rukovodiocima zbirki vodi brigu o upotpunjavanju dokumentacije, za cjelokupno poslovanje muzeja, a napose za naučnu i kulturno-prosvjetnu djelatnost muzeja i njegovu građu, te koordinira sistematizaciju dokumentacije stručnih arhiva pojedinih odjela.” (Pravila Etnografskoga muzeja 1961.).

7 Odjel inventara i depoa se tek dijelom odnosi na dokumentaciju s obzirom da je obuhvaćao "vođenje i čuvanje knjiga muzejskog inventara, vođenje i čuvanje kataloga i muzejskih predmeta, briga oko materijalnog očuvanja deponirane muzejske građe, vođenje evidencije o ulasku i izlasku predmeta iz depoa..." (Pravila Etnografskoga muzeja 1961.).

8 Odsjek Inventar "obuhvaća dokumentaciju o muzejskom fundusu, tj. o svakom predmetu muzejske zbirke uvedenom u inventarne knjige i odgovarajuće kartoteke". Uz navedeno, prema Pravilniku o sistematizaciji radnih mjesta iz 1966. godine "brine da svaki predmet koji udje u bilo koju zbirku bude inventiran i proveden kroz odgovarajuće knjige i kartoteke. Vodi evidenciju nad posudbom muzejskih inventarnih predmeta." Odsjek Dokumentacija "obuhvaća evidenciju terenske dokumentacije i vodi: 1) arhiv (stručni arhiv dokumentacione građe prema Pravilniku o sistematizaciji radnih mjesta, 1966.) i hemeroteku, 2) ilustrativni materijal, fonoteku, filmoteku, fototeku i dijateku." (Statut Etnografskog muzeja u Zagrebu 1966., Pravilnik o sistematizaciji radnih mjesta 1966.). U Statutu Etnografskoga muzeja u Zagrebu iz 1970. godine Odsjek dokumentacije uz već navedene poslove obuhvaća i "praćenje izdavačke djelatnosti s područja etnologije i srodnih struka i nabavljanje prinove; izradu stručne bibliografije".

9 Prema opisu poslova iz Pravilnika stručnjak za vođenje dokumentacije "u suradnji sa stručnjacima i pod njihovim vodstvom inventarizira cjelokupni materijal odsjeka: terenski zapisnici i ostala terenska dokumentacija, fotosnimke, te sve vrsti slikovnog dokumentacionog materijala kao i fono-snimke i priprema ih za deponiranje; unosi novi materijal u Ulazne knjige dokumentacije; vodi evidenciju o smještaju kao i o posudbi; u suradnji sa stručnjacima izrađuje matične i specijalne kartoteke; obavlja sve ostale tehničke poslove vezane za evidenciju i dokumentaciju." (Pravilnik o sistematizaciji radnih mjesta 1966.). Pročišćeni tekst Pravilnika o sistematizaciji radnih mjesta iz 1972. navodi kako ove poslove obavljaju "u smislu odredbe čl. 3 ovog Pravilnika - kustosi, viši kustosi i stručnjaci ostalih naučnih zvanja".

Prema opisu poslova iz Pravilnika stručnjak za vođenje Inventara etnografske građe "vodi evidenciju ponude i 
Ta podjela zadržana je tijekom narednih godina u statutima i pravilnicima kojima je propisano unutarnje ustrojstvo Muzeja. U Pravilniku o sistematizaciji radnih mjesta iz 1977. godine Dokumentacija je kao jedinica izdvojena unutar Stručno-znanstvenoga odjela, a činili su ju Inventar muzejske građe i kartoteke te Arhiv dokumentacione građe. ${ }^{10}$ Podjela je zadržana i u Statutu donesenom 5. studenoga 1987. godine u kojem je Dokumentacija zasebna jedinica.

U radu iz 1989. Nada Gjetvaj navodi da se stručna dokumentacija muzeja sastoji od Dokumentacije muzejske građe (inventarne knjige, kartoteke, knjiga izlaska, knjiga ulaska), Fototeke i ilustrativnog materijala (inventarna knjiga negativa, inventarna knjiga Foto-arhiv, inventarna knjiga diapozitiva, inventarna knjiga ilustrativne građe, kartoteke) te Stručnoga arhiva (evidencija stručne građe, kartoteka) što je na tragu današnje podjele dokumentacije Muzeja (Gjetvaj 1989: 60-62).

Tijekom sljedećih godina dokumentacija je zasebna ustrojbena jedinica, Odsjek dokumentacije, sve do 2005. godine. Odlukom o izmjenama i dopunama Statuta Etnografskoga muzeja ${ }^{11}$ donesenom 4. svibnja 2005. godine dokumentacija je dio Odjela zbirki i dokumentacije kao i prema trenutno važećem Pravilniku o unutrašnjem ustrojstvu i načinu rada Etnografskoga muzeja od 13. lipnja 2018. godine te Statutu Etnografskog muzeja donesenom 13. prosinca 2018. godine. Dokumentacija prema tim aktima, a sukladno Pravilniku o sadržaju i načinu vođenja muzejske dokumentacije o muzejskoj građi, obuhvaća rad na primarnoj dokumentaciji, fondovima sekundarne te tercijarnu dokumentaciju.

\section{VOĐENJE DOKUMENTACIJE U ETNOGRAFSKOM MUZEJU}

Dokumentacija o muzejskoj građi u Etnografskom muzeju vodi se od samog osnutka muzeja kada je u muzejski fundus ušlo oko 20000 jedinica građe. Naredbom o osnivanju Etnografskog odjela Hrvatskog narodnog muzeja iz 1919. godine objedinjene su sve veće etnografske zbirke Hrvatskoga narodnog muzeja u Zagrebu. Uz te temeljne zbirke muzeja nastaje i dokumentacija vezana uz njih, odnosno inventarne knjige sa signaturama dodijeljenim prema izvoru iz kojega je zbirka došla (AH, UO, B, ŠM, BK). Odmah po osnutku muzeja uvedena je i zajednička inventarna knjiga (Ethnographica) u koju su pod prvih pet brojeva upisane temeljne zbirke kao cjeline. ${ }^{12}$ Tako je tek s brojem

otkupa muzejskih predmeta; vodi Glavnu Inventarnu knjigu, Knjige ulaska i Knjigu izlaska, te privremene knjige inventara; vodi i sredjuje kartoteke na osnovu Glavne inventarne knjige, tj. kartoteke po predmetu, po lokalitetu, po rednom broju; vodi evidenciju posudbe muzejskih predmeta; suradjuje s voditeljima zbirki i brine se za ažurnost inventiranja" (Pravilnik o sistematizaciji radnih mjesta 1966). Pravilnik o sistematizaciji radnih mjesta iz 1972. navodi kako ove poslove obavljaju "u smislu odredbe čl. 3 ovog Pravilnika - kustosi, preparatori i konzervatori - tehničari." Poslije su u Pravilniku o sistematizaciji poslova i radnih zadataka iz 1980. godine navedena radna mjesta dokumentarist - muzejski stručnjak i inventarist.

10 Inventar muzejske građe i kartoteke vodi propisane knjige i kartoteke. Brine se da svaki predmet koji uđe u bilo koju zbirku bude inventiran i proveden kroz odgovarajuće knjige i kartoteke. Arhiv dokumentacijske građe vodi stručni arhiv dokumentacijske građe s terena, kao i ostalu rukopisnu građu. Vodi brigu o fototeci, filmoteci, diateci, fonoteci i drugom ilustrativnom materijalu. (Gjetvaj 1989: 56-57).

11 Pohranjen u arhivi Etnografskoga muzeja u Zagrebu.

12 Tako je pod brojem (Et) 1 upisana etnografska zbirka Historijsko-arheološkoga odjela Narodnoga muzeja u 
šest u zajedničkoj inventarnoj knjizi slijedio upis predmeta koji su otkupom ili darom ulazili u fundus muzeja. Tijekom narednih godina uvedeno je još nekoliko inventarnih knjiga različitih signatura poput ZGZ, ES, Va, Ex, G te Arcana. ${ }^{13}$

Paralelno s prikupljanjem muzejske građe prikuplja se i dokumentacijska građa zahvaljujući Vladimiru Tkalčiću i Milovanu Gavazziju, odnosno njihovim intenzivnim i sustavnim terenskim istraživanjima započetima odmah po osnutku muzeja. ${ }^{14}$ Građa je prikupljana u svrhu proučavanja, rekognosticiranja terena te istraživanja etnografskih tema uz primjenu fotografskoga, filmskoga i fonografskoga snimanja.

"Za tih je dužih i kraćih putovanja sabrana (bilo kao dar pojedinaca bilo kupnjom) sva sila interesantnih i vrijednih objekata, koji su u velike popunili mnogu dosadašnju prazninu muzejske zbirke. Sakupljeni podatci o pučkom životu, velik broj učinjenih fotografskih snimaka i raznovrsnih crteža udarili su temelj etnografskom arkivu muzeja”. (Tkalčić 1922: 75) (Sl. 1.)

Uz brojnu audiovizualnu građu danas se u Dokumentaciji Etnografskoga muzeja nalazi dokumentacija vezana uz povijest i djelovanje muzeja - statuti, pravilnici i drugi normativni akti, zapisnici, izvještaji, dopisi, evidencije, dokumentacija vezana uz terenska istraživanja i stručni rad, hemeroteka, dokumentacija o stalnim postavima i izložbama, izdavačkoj djelatnosti - katalozi, plakati, pozivnice, časopisi i dr. Hemerotečna građa je sve do 2005. godine bila prikupljana u knjižnici muzeja, nakon čega je pohranjena u dokumentaciji gdje je nastavljeno prikupljanje, ali bez vođenja evidencije i stručne obrade koja je započeta tijekom 2019. godine. U knjižnici su prikupljani i plakati vezani uz izložbenu djelatnost Etnografskoga muzeja, ali i drugih hrvatskih i inozemnih muzeja. Izložbeni plakati vezani uz izložbenu djelatnost Etnografskoga muzeja 2017. godine pohranjeni su u dokumentaciji.

Razina svijesti o važnosti prikupljanja, čuvanja, evidentiranja i stručne obrade dokumentacijske građe prisutna je već u samim početcima djelovanja muzeja, ali se kao i politike prikupljanja toga gradiva, mijenjala tijekom godina. Naime, u prethodnim razdobljima dokumentacijska građa nije bila pohranjivana isključivo u dokumentaciji

Zagrebu - (AH) 1163 inventarna broja, (Et) 2 zbirka proizvoda pučkoga obrta pod nazivom "Zbirka Berger" - (B) 8183 inventarna broja, (Et) 3 zbirke iz Trgovačko obrtne komore u Zagrebu - (BK) 1206 inventarnih brojeva, (Et) 4 zbirka iz Hrvatskoga muzeja pedagoško-književnoga zbora u Zagrebu - (ŠM) 922 inventarna broja, (Et) 5 zbirka Muzeja za umjetnost i obrt kraljevske obrtne škole u Zagrebu - (UO) 4503 inventarna broja (Gjetvaj 1989: 60, Zorić 2015: 54).

13 Knjiga signature ZGZ, uvedena je 1928. godine, a u nju su se unosili predmeti otkupljeni sredstvima Grada Zagreba do 1940. godine. Signatura ES označavala je Etnološki seminar te su u njoj upisani predmeti koji su bili dijelom u vlasništvu Etnografskoga muzeja, a dijelom Odsjeka za etnologiju Filozofskoga fakulteta Sveučilišta u Zagrebu te su služili u nastavne svrhe. U Variu su ušli lako kvarljivi i predmeti podložni oštećenjima. Exota - Ex uvedena je 1970-ih, a u njoj se trebala inventirati građa izvaneuropske provenijencije iz zbirke Historijsko-arheološkoga odjela Narodnoga muzeja u Zagrebu (AH), no, taj princip nije uvijek dosljedno proveden pa se dio nastavio voditi u zajedničkoj inventarnoj knjizi, a dio u knjizi Ex. U knjigu sa signaturom G upisani su predmeti koji su došli u muzej posredstvom ili darom prof. Gavazzija, no prije su inventirani u Ethnographici (prema podatcima iz Inventarne knjige G predmeti su zaprimljeni u razdoblju od 1921. do 1937. godine). U inventarnu knjigu Arcana upisano je tek tri inventarna broja za predmete usko vezane uz intimu (kalafićur i dva nakurnjaka) (Zorić 2015: 54).

14 Među značajnijim istraživanjima u prvim godinama djelovanja Muzeja svakako se ističe Pokupska ekspedicija iz 1923. godine. (vidi u Muraj, Aleksandra; Eckhel, Nerina; Zorić, Vesna: Pokupska sjećanja: Etnografska ekspedicija 1923. Etnografski muzej, Zagreb. 1993.) Kasnijih godina ističu se primjerice istraživanja okolice Zagreba (Resnik 1969., Čučerje 1974., Ščitarjevo 1975., Markuševec 1976., Šestine 1979.). 
te se danas čuva na nekoliko mjesta - tajništvo muzeja, Hrvatski državni arhiv ${ }^{15}$ te u osobnim arhivima djelatnika koji postupno ulaze u dokumentacijske fondove muzeja kao pojedinačni darovi ili čitave ostavštine. S obzirom na iznimnu informacijsku vrijednost građe prisutno je nastojanje da se ona postupno, u skladu s mogućnostima, objedini, sistematizira, obradi i digitalizira te učiniti dostupnom.

Ubrzo nakon osnutka Muzeja, krajem 1920-ih godina, uz navedene inventarne knjige muzejskih predmeta uvedene su knjiga ulaza i knjiga izlaza muzejskih predmeta te kartoteka s kataloškim listićima vođena prema inventarnom broju, predmetu i lokalitetu. Također su uvedeni i Foto-arhiv, inventarne knjige negativa, dijapozitiva i ilustrativne građe te evidencija stručnoga rada, ${ }^{16}$ a vođena je i kartoteka s kataloškim listićima za foto-arhiv, negative, dijapozitive (prema predmetu i lokalitetu) i stručni rad (prema autoru, vrsti rada i lokalitetu).

Ključnu ulogu u procesu nastajanja navedene dokumentacije imali su kustosi, ali svakako treba istaknuti i rad kolegica Tereze Paulić, Zdenke Sertić i Blaženke Szenczi koje su svojim radovima (crtežima, skicama, nacrtima i sl.) vizualno značajno obogatile dokumentaciju i dokumentacijsku građu Etnografskoga muzeja. (Sl. 2.)

\section{MUZEJSKI STRUČNJACI U ULOZI DOKUMENTARISTA}

U početcima djelovanja muzeja za vođenje dokumentacije o muzejskim predmetima bili su zaduženi tadašnji muzejski stručnjaci, odnosno Vladimir Tkalčić i Tereza Paulić koja je prema trenutno dostupnim izvorima obavljala poslove inventarizacije te nastavila voditi dokumentaciju nakon Tkalčićeva odlaska 1934. godine (Gjetvaj 1989: 51; Mokos 2011: 13). U narednom razdoblju ističe se uloga Paole Gabrić kroz bavljenje problematikom vođenja dokumentacije o muzejskim predmetima te Blaženke Szenczi koja je inventarizirala i katalogizirala brojne premete u razdoblju od 1941. do 1975. godine (Ibid.: 19, 24). Nakon preuređenja muzeja 1972. godine vođenje dokumentacije sve do odlaska u mirovinu 1995. godine preuzima Nada Gjetvaj (Ibid.: 27-28). Poslove u dokumentaciji uz Nadu Gjetvaj obavljaju Ivanka Ivkanec (u razdoblju od 1973. do 1976. godine) i Emilija Rona (inventaristica u razdoblju od 1974. do 1994. godine) (Ibid.: 33). Posao inventaristice, zatim i dokumentaristice od 1995. do 2016. godine obavlja Jasna Mokos (Ibid.: 35). Od kraja 2016. godine poslove vođenja muzejske dokumentacije preuzima dokumentaristica i autorica ovog teksta Aleksandra Vlatković.

Uz navedene kolegice i kolege brigu o audiovizualnoj građi vodili su Marcel Davila (u razdoblju od 1942. do 1969. godine), Nada Gjetvaj (od 1972. do 1995. godine), Mladen Tomljenović (od 1995. do 2013. godine) te Matija Dronjić koji vođenje Audiovizualnih fondova preuzima 2013.: godine (Ibid. 18, 27-28, 18, 27-28, 42). ${ }^{17}$

15 Etnografski muzej je dokumentacijsku građu u nekoliko navrata u razdoblju od 1968. do 1990. godine predao Hrvatskom državnom arhivu. http://arhinet.arhiv.hr/details.aspx?ItemId=1_4443 (pristup 10. lipnja 2019.).

16 Evidencija stručnoga rada vođena je od 1972. do 2005. godine. Preostala dokumentacijska građa je prikupljana te tek djelomice sistematizirana i popisana.

17 Literatura koja se bavi načinom rada i poviješću muzejske dokumentacije Etnografskoga muzeja u Zagrebu ne obrađuje detaljno poslove vezane uz način rada i vođenje dokumentacija u Muzeju niti donosi jasan pregled 
Kako je vidljivo iz ovoga kratkog pregleda kustosi i pojedini stručnjaci muzeja bili su zaduženi za poslove vezane uz vođenje i organizaciju dokumentacije te su ujedno prikupljali i tek dijelom obrađivali i evidentirali dokumentacijsku građu. U procesu stvaranja temelja i razvoja dokumentacije Muzeja ističe se doprinos nekoliko ključnih osoba. Stoga u nastavku teksta tek upućujem na njih kao poticaj za daljnje opsežnije istraživanje koje je svakako potrebno provesti kako bi se dobio detaljniji uvid i jasnija slika njihova rada, uloge te značaja i doprinosa u kontekstu vođenja dokumentacije, ne samo u okviru Etnografskoga muzeja, nego i izvan njega.

Vladimir Tkalčić (1883. - 1971.) kao prvi kustos Etnografskoga muzeja, u kojem je radio od 1919. do 1934. godine, nastojao je sustavno i kvalitetno obraditi predmete koji su prilikom osnutka muzeja ušli u muzejski fundus. Upravo zahvaljujući njemu s početkom djelovanja muzeja postavljeni su temelji stručnoga i znanstvenoga rada s obzirom da je oblikovao prve zbirke predmeta, pokrenuo inventarizaciju fundusa te ustanovio dokumentacijske fondove (Zorić 2015: 53). Tako je odmah po osnutku muzeja uveo inventarnu knjigu, glavnu i pomoćne kartoteke, knjigu ulaska i izlaska muzejskih predmeta. Inventarne knjige i kartoteke uveo je i za dokumentacijske fondove (Fotoarhiv, negativi, dijapozitivi i ilustrativna građa).

Paula Gabrić (1909. - 1989.) je kao kustosica radila u Etnografskom muzeju od 1948. do 1978. godine. Bila je voditeljica nekadašnjega odsjeka Osnovni zanati i rukotvorstva unutar kojega je vodila zbirku predmeta za obradu drva, slame, metala, kože, krzna i kamena. Unutar odsjeka Nošnje vodila je zbirku nošnji sjeverozapadnoga dijela panonske Hrvatske (Moslavina, Posavina, Pokuplje i Podravina). Uz rad na zbirkama tako je napravila i opsežnu analizu situacije vezane uz inventarizaciju i katalogiziranje muzejske građe u domaćim i svjetskim muzejima te predložila rješenja vezana uz probleme vođenja dokumentacije etnografskih zbirki. ${ }^{18}$ Kod izrade prijedloga držala se obaveznoga sistema evidentiranja muzejskih zbirki u muzejima tadašnje Jugoslavije koje je izdalo Savezno ministarstvo za nauku i kulturu 1950. godine (Gabrić 1954: 31). Metodološke okvire u vođenju dokumentacije o muzejskoj građi predstavila je u svom radu "Katalog Etnografskog muzeja: inventiranje muzejskih predmeta i sistem inventarnih knjiga te katalogiziranje s naročitim osvrtom na specifičnosti etnografske struke" iz 1954. godine. U radu donosi prijedlog novoga načina stručne obrade građe kroz detaljne upute dodjeljivanja inventarnih brojeva, dimenzije i materijal glavne inventarne knjige, izgled i sadržaj kataloške kartice, inventarnoga omota, priručnih kartoteka kao i prijedlog grupa za predmetni katalog (Gabrić 1954.; Zorić 2015: 55). Svakako treba istaknuti činjenicu kako je kolegica Gabrić bila u korak s tadašnjim muzeološkim tendencijama.

djelatnika koji su radili poslove vezane uz dokumentaciju. Podatci iz literature uglavnom se odnose na praksu i metodologiju rada na dokumentaciji. Kako inventarne knjige ne sadrže podatak o odgovornosti za upis, a na karticama je tek djelomice zabilježen, slijed osoba zaduženih za poslove dokumentacije nastojala sam rekonstruirati kroz trenutno dostupnu literaturu te arhivsku i dokumentacijsku građu. Podatke o radu u dokumentaciji pronašla sam u katalogu izložbe "Djelatnici Etnografskoga muzeja u Zagrebu" (2009.), autorice Jasne Mokos, u natuknicama o radu pojedinih kolega. Međutim, upravo zbog određenih praznina između pojedinih razdoblja te nedovoljno preciziranih zaduženja za detaljniju analizu je potrebno provesti dodatno istraživanje ponajprije muzejskoga arhiva, što ostavljam za buduću razradu te ovdje donosim samo kratki prikaz.

18 U arhivu muzeja postoji niz dokumenata koji potvrđuju bogatu korespondenciju s najznačajnijim etnolozima i muzejskim stručnjacima Europe poput Claude Lévi-Straussa, Georges Henri Riviérea ili Andreasa Lommela, u kojima se doznaje o njihovim metodama inventiranja i katalogiziranja (Zorić 2015: 55). 
Naime, o važnosti i značenju kvalitetne stručne obrade intenzivno se na svjetskoj razini počelo raspravljati sredinom 20. stoljeća. Tih godina vrlo je aktualan bio i muzeolog Antun Bauer te je promišljajući tu temu u časopisu Muzeologija objavio tekst "Neke primjedbe na stručno inventiranje u muzejima“. U tekstu ističe kako je "stručno inventiranje muzejskog materijala možda najviše zanemareni dio rada naših muzeja" (Bauer 1956: 16), a kao razlog tomu navodi pomanjkanje "jednog jasnog i odredjenog sistema stručnog muzejskog inventara zbog čega većina stručnog muzejskog personala i zazire od tog posla" (Ibid.: 16). Nadalje, Etnografski muzej, odnosno rad Paule Gabrić ističe kao dobar primjer te navodi:

"Nesumnjivo je najsolidnije prostudirana radnja kolegice prof. Paule Gabrić, kustosa Etnografskog muzeja u Zagrebu, koja donosi rješenje problema o inventiranju etnografske zbirke, bila povod da su muzeji u Djakovu i Osijeku uveli ovaj sistem inventiranja za etnografsku građu u svojim zbirkama. To su vjerojatno najsolidnije uredjeni muzejski inventari u našim muzejima." (Ibid.: 20)

Prijedlozi rješenja do kojih je došla u Etnografskom muzeju bili su tek dijelom prihvaćeni te su 1960-ih, počevši od inventarnoga broja 19.001, uvedene nove rubrike u inventarnoj knjizi i kataloškoj kartici kojoj je promijenjen i izgled. ${ }^{19}$

Nada Gjetvaj (1930.) je kao kustosica u Etnografskom muzeju radila od 1955. do 1995. godine, a uz rad na zbirkama koje je vodila bila je zadužena i za dokumentaciju. Nastavila je dotadašnju praksu vođenja dokumentacije o muzejskim predmetima, a 1972. godine uvela je vođenje evidencije Stručne građe (izvještaji s terena, terenski zapisi, upitnice i sl. građa) zajedno s priručnom kartotekom. U svom magistarskom radu "Historijat i perspektivni razvoj Etnografskog muzeja u Zagrebu”, koji je obranila 1981. godine, te prilagodila za objavu u časopisu Etnološka istraživanja 1989. godine pod naslovom "Etnografski muzej u Zagrebu - u povodu 70. obljetnice" donosi sistematičan pregled povijesti, organizacije i djelovanja muzeja. Taj rad od iznimne je pomoći prilikom sistematizacije dokumentacijskih fondova te su izvor brojnih informacija tijekom stručne obrade dokumentacijske građe koja je pohranjena u dokumentaciji, a za koju popisi, evidencije i podatci ne postoje ili su vrlo oskudni (izložbena djelatnost, stručni i znanstveni rad, dokumentacija s terenskih istraživanja i sl.).

Rad kolegice Gjetvaj spona je koja će uvelike pomoći u nadolazećoj fazi rada na dokumentaciji Etnografskoga muzeja koja je naznačena u nastavku teksta. U tom procesu u planu je trenutno stanje i strukturu dokumentacijske građe Etnografskoga muzeja povezati i ustrojiti u skladu s praksama i fondovima utemeljenim neposredno po osnutku muzeja uvažavajući pri tom suvremene muzeološke prakse i zakonske okvire.

19 Rubrike u inventarnoj knjizi: inv. br. /kategorija spom. vrijednosti / broj knjige ulaska / zbirka, odjeljenje / opis / autor, proizvođač / vrijeme postanka / materijal, tehnika / veličina, težina / broj komada / stanje, zaštitni zahvati / provenijencija: mjesto izvedbe, mjesto upotrebe, mjesto nalaza / način nabavke, datum, br. spisa / ime i adresa prodavaoca ili darovatelja / cijena / foto, dia / inventarni omot / smještaj / napomena. Kataloška kartica obuhvaćala je sljedeće podatke: inventarni broj / zbirka; grupa; podgrupa / naziv muzeja / lokalitet / književni naziv / naziv u dijalektu / vrijeme porijekla / lokalitet proizvodnje / da li je original, reprodukcija, kopija / kada i kako je dospio u muzej / materijal / tehnika / ornament / stanje / opis / komada / dimenzije / težina / osnovna funkcija / nabavna cijena / kategorija vrijednosti / sign. smještaja / sign. fototeke / inventarni omot / bilješka / opis - nastavak / literatura / restauratorski zahvati / inventirao. 


\section{DOKUMENTACIJA DANAS}

Dokumentacija Etnografskoga muzeja u Zagrebu danas se vodi u skladu s važećim zakonskim propisima, ponajprije sa Zakonom o muzejima (NN 61/2018) i Pravilnikom o sadržaju i načinu vođenja muzejske dokumentacije o muzejskoj građi (NN 108/2002). Rad na dokumentaciji i dokumentacijskoj građi trenutno je u procesu reorganizacije koja se odnosi ponajprije na vođenje sekundarnih fondova, s ciljem da se praksa u potpunosti uskladi s važećim propisima. Ipak, u ovom procesu nastoji se poštivati dosadašnja tradicija i praksa s obzirom da su temelji vođenja dokumentacije u Etnografskom muzeju postavljeni prije zakonskih okvira i regulativa. Prema Pravilniku muzejska dokumentacija se dijeli na primarnu, sekundarnu i tercijarnu te u nastavku teksta donosim prikaz trenutne situacije u Dokumentaciji Etnografskoga muzeja prema ovoj podjeli.

Primarna dokumentacija Etnografskoga muzeja vodi se u računalnom programu za obradu muzejske građe M++. Sastoji se od inventarne knjige, kataloga, knjige ulaska i knjige izlaska muzejskih predmeta te knjige pohrane. Primarnu dokumentaciji prema Pravilniku o sadržaju i načinu vođenja muzejske dokumentacije o muzejskoj građi (NN 108/2002) čine i zapisnici o reviziji muzejske građe. ${ }^{20}$ Prva službena revizija cjelovitoga fundusa provedena je 2016. godine te je u dokumentaciji pohranjeno i evidentirano ukupno 45 zapisnika o reviziji zbirki s popratnom dokumentacijom. Sređivanjem i sistematizacijom dokumentacijske građe, koja je u tijeku, ovim zapisnicima su pridruženi zapisnici o primopredajama ili revizijama pojedinih zbirki koji su tijekom prethodnih godina pohranjeni u Dokumentaciji. Prioritet rada na primarnoj dokumentaciji trenutno je priprema inventarne knjige za ispis revizijskih popisa iz baze kako bi se osigurao ujednačeni pristup koji će omogućiti kvalitetnije provođenje analize rezultata revizije s ciljem sravnjivanja stanja na razini zbirki i fundusa.

Sekundarna dokumentacija vodi se u relacijskoj bazi $\mathrm{S}++.{ }^{21}$ Kako je u tekstu već naznačeno, prije računalne obrade, vođene su inventarne knjige za audiovizualnu građu dok se preostala dokumentacijska građa prikupljala i pohranjivala u dokumentaciji, ali bez detaljnijih popisa, evidencija ili inventarnih knjiga. Upravo stoga rad na dokumentacijskoj građi je u fazi analize njezine strukture kroz sadržaj i vrstu građe nakon čega slijede procesi sistematiziranja u cjeline, odgovarajuće dokumentacijske fondove te stručna obrada. Dosadašnjim uvidom u dokumentaciji je prikupljana građa koja se odnosila na muzejske predmete, djelovanje muzeja i stručni rad djelatnika kao i različiti dopisi, izvještaji, zapisnici, normativni akti i druga slična građa. Sistematizacija zatečene dokumentacijske građe vođena je idejom poštivanja politike prikupljanja dokumentacijske građe i kontinuiteta vođenja dokumentacije u Etnografskom muzeju, a u skladu s važećim propisima. Sistematizirana dokumentacijska građa vodit će se kroz fondove hemeroteka, izložbe, izdavačka djelatnost, stručni i znanstveni rad, pedagoška

20 Inventarna knjiga muzejskih predmeta uvedena je po osnutku muzeja, a ubrzo je uvedena i kartoteka te knjige ulaska i izlaska. Pohrane muzeja vode se kroz evidencijske popise predmeta sastavljene prilikom ulaska cjeline u Muzej. Prelaskom na računalnu obradu muzejske građe svi navedeni oblici dokumentacije vode se u digitalnom obliku $(\mathrm{M}++)$.

21 Audiovizualni fondovi u S + + vode se od uvođenja programa 2009. godine, a dokumentacijski fondovi od 2017. godine. 
djelatnost, događanja, konzervatorsko-restauratorski postupci, dokumenti o osnivanju i povijesti muzeja te stručni arhiv.

Tercijarna dokumentacija je u obliku kataloških listića uvedena u prvim godinama djelovanja muzeja zahvaljujući ponajprije V. Tkalčiću i M. Gavazziju koji su prepoznali potrebu za implementacijom sustava upravljanja podataka. ${ }^{22}$ Današnji sustav obrade muzejske građe i dokumentacije u računalnom obliku tercijarnu dokumentaciju vodi kroz nadzor nazivlja koji se postiže primjenom kontroliranih rječnika i tezaurusa, a u svrhu poboljšanja dostupnosti i kvalitetnijega pretraživanja. Uvidjevši važnost rada na tercijarnoj dokumentaciji Etnografski muzej uključen je u izradu klasifikacije prijedlogom dopune iz 1990. godine, a 2006. godine preko sustava matičnosti pokrenut je projekt izrade i razvoja nazivlja, odnosno tezaurusa za etnografske muzejske predmete na razini Republike Hrvatske. ${ }^{23}$

\section{PROCES DIGITALIZACIJE}

Uvođenjem novih tehnologija u muzeje nastojalo se ujednačiti i standardizirati pristup obrade predmeta unatoč razlikama i specifičnostima pojedinih struka, a sve s ciljem poboljšanja i povećanja dostupnosti građe. Digitalizacija je proces koji je u Etnografskom muzeju u Zagrebu započeo paralelno s informatizacijom muzejske djelatnosti u Hrvatskoj početkom 1990-ih u okviru projekta MUGIS (Museum and Galleries Information System) kojim je MDC ponudio program MODES (Zorić 2002: 315). Etnografski muzej sredinom 1990-ih godina s informatičkom tvrtkom Microlab razvija program za računalnu obradu podataka o muzejskim predmetima Promus (Ibid 2002: 316). Od 2009. godine Muzej uvodi programski paket za računalno vođenje muzejske dokumentacije $\mathrm{M}++{ }^{24}$ koja je dodatno prilagođena s obzirom na specifičnosti struke (Zorić 2015: 56). Od uvođenja do danas program se konstantno razvija kroz suradnju muzejskih, informacijskih i informatičkih stručnjaka prateći na taj način standarde i metode suvremene muzeologije i pojedinih struka, ali i razvoj tehnologije. Trenutno je aktualan prelazak i razvoj mrežne aplikacije Modulor $++{ }^{25}$ Program Modulor ++ uveden je u Etnografski muzej sredinom 2017. godine te je dio kustosa počeo rad u njemu.

Cilj procesa digitalizacije jest sačuvati i zaštiti muzejsku građu i dokumentaciju, ali istovremeno i omogućiti bolji uvid, lakše pretraživanje i dostupnost podataka, odnosno baštine, kako stručnjacima, tako i široj zajednici korisnika. Navedene ciljeve Etnograf-

22 Uz glavnu kartoteku muzejske građe sortiranu prema inventarnom broju u Dokumentaciji se nalaze i pomoćne kartoteke prema vrsti predmeta i lokalitetu. Za dokumentacijske fondove postoji kartoteka negativa prema vrsti predmeta i lokalitetu te Stručnoga arhiva prema autoru, vrsti građe i lokalitetu.

23 Prijedlog za dopunu klasifikacije muzejskih predmeta za područje etnografije sastavila je radna grupa Etnografskoga muzeja u sastavu: M. Randić Barlek, I. Šestan, A. Brenko, N. Eckhel (Fruk 1990: 25). Na izradi tezaurusa radile su I. Kolbas i A. Vlatković u razdoblju od 2006. do 2012. godine kada je iz više razloga prekinut rad na tezaurusu.

24 Muzejska građa vodi se u modulu za vođenje primarne dokumentacije $\mathrm{M}++$, dok se građa dokumentacijskih fondova vodi u relacijskoj bazi podataka $\mathrm{S}++$.

25 Modulor ++ "osigurava integrirani pristup bazama podataka $\mathrm{M}++, \mathrm{S}++, \mathrm{K}++$ putem bilo kojeg mrežnog preglednika. Podržana je primjena aplikacije u računalnom oblaku, što omogućuje dostupnost na internetu, ili uvođenje aplikacije na lokalnoj mreži ustanove..." (Zlodi 2016: 253-254). 
ski muzej nastoji ostvariti kroz do sada realizirane projekte ili one koji su trenutno u pripremi. Tijekom prethodnih godina u cijelosti su digitalizirane i javnosti dostupne Zbirka Perinić i Zbirka tradicionalnih afričkih umjetnina Drage Muvrina, zatim dio Zbirke izvaneuropskih kultura digitaliziran kroz projekt "Istraživanja braće Seljan" te dio Zbirke glazbala kroz projekt "S hrvatskom tradicijskom glazbenom baštinom u svijet". U tijeku je i digitalizacija dijela Fototeke kroz pilot projekt "Etnografski muzej online". Uz dio Fototeke digitaliziran je, ali trenutno ne i javno dostupan, dio dokumentacijske građe poput negativa na staklu i rukopisne građe.

\section{UMJESTO ZAKLJUČKA}

U skladu s razvojem tehnologije, ali i s obzirom na suvremenu muzeologiju te važeće zakonske okvire, izmijenjena je uloga dokumentacije i dokumentarista u muzejima. Jedan od ciljeva dokumentiranja jest upotreba dokumentacije (Maroević 1993: 194), a muzejska dokumentacija danas sve više podrazumijeva komunikaciju s korisnicima različitih skupina, od djelatnika muzeja, kolega, stručnjaka različitih profila, studenata sve do šire zajednice korisnika u realnom i u virtualnom prostoru. U Etnografskom muzeju, kako je prilikom svog izlaganja na stručno-znanstvenom seminaru Digitalna humanistika ${ }^{26}$ istaknuo kolega Matija Dronjić, "prisutan je dugogodišnji kontinuitet, kreativnog korištenja muzejske dokumentacije" kroz projekte digitalizacije, tiskane kataloge, izložbene projekte, ali i kroz mrežnu stranicu muzeja gdje je dijelom vidljiva i dostupna sekundarna dokumentacija kroz izložbe, posebna događanja te izdavačku djelatnost.

Tijekom 100 godina djelovanja Etnografskoga muzeja, a u širem kontekstu muzejskih teorija, zakonskih okvira i muzejskih praksi koje su predstavljene u tekstu očito je da uloga muzejskoga dokumentarista višestruko nadilazi nekadašnje poslove vezane ponajprije uz prepisivanje podataka. Dokumentarist Etnografskoga muzeja u Zagrebu danas, uz vođenje fondova sekundarne dokumentacije i obradu dokumentacijske građe, ima sve značajniju ulogu u procesima vezanim upravo uz upotrebu dokumentacije i komunikaciju s korisnicima različitih skupina. Ponajprije kada je riječ o standardizaciji i uređivanju (meta)podatka jer tek kvalitetno pripremljena dokumentacija ima potencijale i mogućnost primjene u suvremenim tehnologijama, odnosno u virtualnoj stvarnosti u kojoj se danas odvija sve veći dio komunikacije.

26 Seminar je održan u Etnografskom muzeju, Zagreb, 1. lipnja 2017. godine, u organizaciji, Hrvatskog etnološkog društva. 


\section{LITERATURA I IZVORI:}

BAUER, Antun. 1956. "Neke primjedbe na stručno inventiranje u muzejima". Muzeologija 5: 16-27.

GABRIĆ, Paula. 1954. "Katalog Etnografskog muzeja: Inventiranje muzejskih predmeta i sistem inventarnih knjiga te katalogiziranje s naročitim osvrtom na specifičnosti etnografske struke". Muzeologija 4: 3-66.

GJETVAJ, Nada. 1989. “Etnografski muzej u Zagrebu - u povodu 70. obljetnice”. Etnološka istraživanja 5.

FRUK, Marinka. 1990. "Informacija o radu Radne grupe za klasifikaciju muzejskih i galerijskih predmeta i dopuna klasifikacije za grupu Umjetnički predmeti i komunikacija i simbol te etnografska građa”. Bulletin o informatizaciji muzejske djelatnosti SR Hrvatske 2: 22-36.

MAROEVIĆ, Ivo. 1993. Uvod u muzeologiju. Zagreb: Zavod za informacijske studije Odsjeka za informacijske znanosti, Filozofski fakultet Sveučilišta u Zagrebu.

MOKOS, Jasna. 2011. "Dokumentacija Etnografskog muzeja u Zagrebu”. Etnološka istraživanja 16: $273-276$.

MURAJ, Aleksandra; ECKHEL, Nerina i Vesna ZORIĆ. 1993. Pokupska sjećanja: Etnografska ekspedicija 1923. Zagreb: Etnografski muzej.

OKLOPČIĆ, Jagoda. 1990. "Muzejski zakoni i zaštita muzejske građe”. Informatica museologica 21/3-4: 26-27.

OSREČKI, Dubravka. 1990. "Dokumentacija kao oblik zaštite muzejskog fundusa”. Informatica museologica. 21/3-4: 27-28.

Pravila Etnografskog muzeja, 1961., Dokumentacija EMZ.

Pravilnik o sadržaju i načinu vođenja muzejske dokumentacije o muzejskoj građi (NN 108/2002).

Pravilnik o sistematizaciji radnih mjesta, 1977., Dokumentacija EMZ.

Pravilnik o stručnim i tehničkim standardima za određivanje vrste muzeja, za njihov rad, te za smještaj muzejske građe i muzejske dokumentacije (NN 30/2006).

s.n. 1989. "Upute o osnovama za vođenje dokumentacije o predmetima". Informatica museologica 19/3-4: 144-147.

Statut Etnografskog muzeja u Zagrebu, 1966., Dokumentacija EMZ.

Statut Etnografskog muzeja u Zagrebu, 1987., Dokumentacija EMZ.

Statut Etnografskog muzeja u Zagrebu, 2018., Dokumentacija EMZ.

ŠOLA, Tomislav, ur. 1987. "Dokumentacija i klasifikacija muzejskih i galerijskih predmeta". Muzeologija 25: 3-117.

TKALČIĆ, Vladimir. 1922. "Etnografski muzej u Zagrebu”. Narodna starina 1: 73-75.

Zakon o muzejima (NN 142/1998, NN 110/2015, NN61/2018).

Zakon o muzejskoj djelatnosti (NN 49/1960, NN 12/1977). 
ZLODI, Goran. 2016. "Uloga Muzejskog dokumentacijskog centra u informatizaciji i digitalnoj transformaciji muzeja u Hrvatskoj”. Muzeologija 53: 234-262.

ZORIĆ, Vesna. 2002. "Iskustva u primjeni računalnog programa Promus u dokumentaciji zbirki Etnografskog muzeja u Zagrebu”. Etnološka istraživanja 8: 315-320.

ZORIĆ, Vesna. 2015. "Stručna obrada građe i registracija zbirki Etnografskog muzeja u Zagrebu”. Etnološka istraživanja 20: 53-59.

www.emz.hr (pristup 3.6.2019.).

http://arhinet.arhiv.hr/details.aspx?ItemId=1_4443 (pristup 10.6.2019.). 